\title{
Fish consumption during menarche, menstruation, pregnancy and postpartum in Sikuani women from Meta, Colombia
}

Luisa Fernanda Cubillos-Cuadrado* (D), Daniela Stephany Muñoz-Hernández and Carlos Alberto Vásquez-Londoño

\begin{abstract}
Background: Societies have selected their food for health, cultural, religious, political, economical, and environmental reasons. Most of the food included in Sikuani traditional diet still comes from wild natural resources and involves numerous species of fish, mammals, birds, reptiles, amphibians, insects, and plants. During certain periods of the Sikuani women's reproductive cycle, fish intake is avoided. The objective of this research is to study the conceptions underlying fish consumption regulations among Sikuani women at the Wacoyo Reservation, in Meta, Colombia.
\end{abstract}

Methods: We conducted a field study through interviews and participant observation with Sikuani Indigenous from the Wacoyo Reservation (Colombia). We inquired about the conceptions of fish consumption regulation by Sikuani women during the stages of the reproductive cycle. PCA (principal component analysis) was used to identify the most important characteristics of fish that are related to the avoidance of fish intake by Sikuani women during pregnancy. This study combines qualitative and quantitative analysis.

Results: It was found that during menarche and postpartum fish consumption is avoided by Sikuani women only before the ritual known as the prayer of the fish is performed. The menstruation does not imply significant regulations for fish intake, while during pregnancy there are multiple and specific avoidances for the consumption of fish. According to our results, there are some features of fish associated with their regulation on the diet of pregnant Sikuani women. The consumption of some fish is avoided during pregnancy because it is related to the appearance of disease caused by ainawi, protector spirits of aquatic animals.

Conclusions: The traditional diet of Sikuani women includes numerous fish species and an important proportion of them are avoided during menarche, menstruation, gestation, and postpartum. According to our results, there are some features of fish associated with their regulation on the diet of pregnant Sikuani women. The main reasons underlying the avoidance of fish consumption by Sikuani women are the prevention of human disease as well as the strengthening of communities and ecosystems resilience.

Keywords: Food avoidance, Sikuani, Menarche, Menstruation, Pregnancy, Postpartum, Fish Consumption

\footnotetext{
*Correspondence: Ifcubillosc@unal.edu.co

Faculty of Medicine, Universidad Nacional de Colombia, Bogotá, Colombia
}

(c) The Author(s). 2019 Open Access This article is distributed under the terms of the Creative Commons Attribution 4.0 International License (http://creativecommons.org/licenses/by/4.0/), which permits unrestricted use, distribution, and reproduction in any medium, provided you give appropriate credit to the original author(s) and the source, provide a link to the Creative Commons license, and indicate if changes were made. The Creative Commons Public Domain Dedication waiver (http://creativecommons.org/publicdomain/zero/1.0/) applies to the data made available in this article, unless otherwise stated. 


\section{Background}

Eating is a biological need and a human experience that is articulated in social, economic, ecological, medical, and cultural dimensions. Food systems are reflections of culture, representations of worldviews and constitute a heritage, since they are the result of historical processes of memory and identity of people $[1,2]$. Societies select their food according to the availability of natural resources, its accessibility in territories with dynamic environmental and social conditions, and also in consonance to diverse and complex conceptual frameworks regarding nutrition, food classification, preferences, and restrictions [3, 4]. Food avoidance can be due to cultural, ecological, health, magical-religious or economic reasons, choices observed in everyday life and in specific events such as festivals, religious celebrations, initiation rituals, hunting expeditions, and funerals, as well as during key moments of the human life cycle such as menarche, menstruation, pregnancy, lactation, and postpartum [5]. Some anthropological theories propose that food taboos could work to preserve the environment by restricting resource consumption, strengthening group cohesion, and cultural identity, as well as identifying and protecting from dangerous foods [6]. Some anthropologists state that foods derived from animals are more commonly restricted than plant-based foods [7]. In the case of the Sikuani ethnic group from South America, the regulations for food intake during a woman's life cycle play an important role in their social organisation, territory management, and cultural expressions [8].

The Sikuani belong to the Guahibo linguistic family, they were originally nomads clustered in clans and inhabited historically the Colombian-Venezuelan plains [9]. Historically, the Sikuani have been displaced from their territories on several periods, during the 16-18th centuries by Spanish settlers who occupied the most fertile areas and confined indigenous people into small rural lands called resguardos (indigenous reservations), and later to the present by missionaries and armed groups $[10,11]$. In Colombia, the Sikuani are currently located in the Orinoco basin and constitute the most numerous indigenous population of the eastern region of the country. Nowadays, the Sikuani reside in sedentary or semi-sedentary conditions along the Manacacías, Meta, Vichada, Guaviare, and Orinoco rivers, in indigenous reservations situated in savannah and jungle areas where they subsist from hunting, fishing, gathering, agriculture, and recently from other economic activities $[12,13]$. Despite the notorious influences of forced displacement on the culture and territory management of Sikuani people, most of their dietary intake still comes from wild natural resources including numerous species of fish, mammals, birds, reptiles, amphibians, insects, and plants $[14,15]$.
According to the Sikuani worldview, nature belongs to spiritual entities called ainawi that inhabit water depths, forests, the underworld, and other landscapes [16], implying that the consumption of most animals by humans can cause disease unless an authorisation of the ainawi is requested by the penajorrobinü or Sikuani shaman through prayers, chants, and other rituals [17]. During crucial moments of Sikuani woman life cycle as the menarche, menstruation, pregnancy, and postpartum, the dietary intake of fish and other animals is avoided as its consumption is associated with different ailments caused by the ainawi, making necessary the performance of a ritual called the prayer of the fish [9, 18-21].

Despite the great diversity of species that still constitute the Sikuani traditional diet, the complexity of food restrictions associated to health and environmental protection, and its importance in their daily life and culture, the regulations for fish consumption during important moments of woman life cycle remain unexplored. The aim of this research is to study the reasons underlying the avoidance of fish consumption during menarche, menstruation, pregnancy, and postpartum of Sikuani women at the Wacoyo Reservation, in Meta, Colombia.

\section{Methods}

\section{Study area}

The Wacoyo Reservation is located at the eastern region of Colombia on the Orinoco river basin, near to the municipality of Puerto Gaitán in the department of Meta, surrounded by the Manacacías and Meta rivers, at the coordinates $4^{\circ} 18^{\prime} 40^{\prime \prime} \mathrm{N}$ and $72^{\circ} 04^{\prime} 46^{\prime \prime} \mathrm{W}$, with temperatures ranging from $20{ }^{\circ} \mathrm{C}$ to $35{ }^{\circ} \mathrm{C}$ (Fig. 1); it is considered a tropical forest [11]. Most of the inhabitants of Wacoyo Reservation belong to the Sikuani ethnic group and arrived in this land after being displaced from their ancestral territories. Despite the influence of centuries of sedentarisation and forced migration, the Sikuani people of Wacoyo have resisted and have been able to preserve their culture $[11,19]$.

According to the Sikuani inhabitants of Wacoyo, their predecessor clans were originated, in a mythical period, from totemic animals called momowi that were the first to populate the Orinoco basin. The current Wacoyo community was founded in 1939 by the Sikuani leader called Antonio Turriego Yepes, but only until the 1980s their land was legalised as a reservation and their indigenous organisations were recognised by the government [14]. In the present day, the Wacoyo Reservation has a local authorities headed by the "captain" who leads the organisation of the community and interacts with the local and national governments. According to the Indigenous Affairs Direction of the Colombian Ministry of Interior, the territory of Wacoyo Reservation has an area of 8200 hectares and in 2016 was inhabited by 1537 

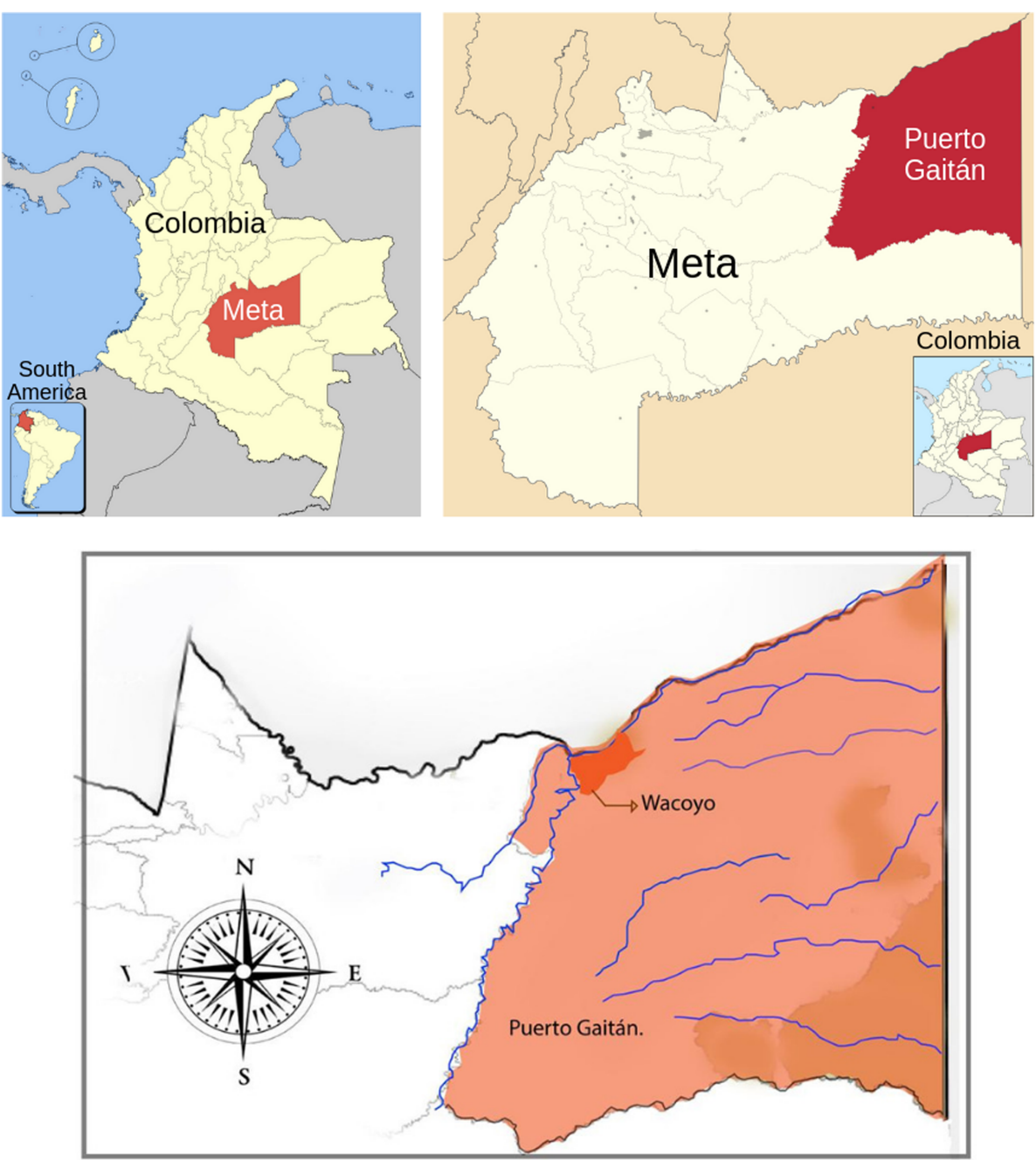

Fig. 1 Location of Wacoyo indigenous reservation in Puerto Gaitán-Meta (orange). From left to right: South America, Colombia, Meta department, Puerto Gaitán, Wacoyo Reservation

people [13]. One of the captains of Wacoyo reported that nowadays, the population of the reservation is approximately 2000 inhabitants. Due to its proximity to rivers, the reservation's food supply is largely obtained not only from fishing, but also from hunting, wild fruits collection and cassava, plantain, and corn crops.

\section{Data collection}

The information was collected from fieldwork during five visits to the Wacoyo Reservation between July 2016 and June 2017. First, the written permit of the community leaders was obtained. As the diet and food restrictions among Sikuani people are complex issues well known by traditional experts, they were considered as the informants for this study. Semi-structured interviews were conducted in 6 families, with a total of 20 people including midwives, traditional healers, leaders, and health promoters of Wacoyo Reservation. Interviews were done in order to inquire about food practices and conceptions during the life cycle stages of the Sikuani woman. Noting that the major food regulations and Sikuani rituals were related to fish consumption, we focused specifically into this topic. Interviewing was done until data saturation was noticed [22]. Additionally, the participant observation technique was used witnessing the daily life of six Sikuani families, observing the acquisition and preparation of traditional foods, as well as rituals like the prayer of the fish performed for a Sikuani girl after her menarche.

For the interviews, colour images of fish were used $[23,24]$. One hundred fifty-eight fish species were selected from local fish inventories [25], informants were asked to identify the images of the species that are part of the diet of Sikuani women, if they were restricted during the menarche, menstruation, pregnancy, or postpartum and which fish features could have an association 
with the avoidance of its intake, including fish size (S), type of food (TF), sharp teeth (ST), fish that disguise $(\mathrm{FD})$, skin plaques $(\mathrm{PP})$, pointed mouth $(\mathrm{PM})$, presence of barbels (PB), snake shape (SS), and big fins (BG).

\section{Data analysis}

Recorded information during field trips was transcribed, then the data collected from each informant and the results of the participant observation were analysed qualitatively using data triangulation [26] and thematic analysis about the diet avoidance during different stages of the Sikuani woman life cycle and conceptions about fish. As data collected from interviews included multiple morphological characteristics of the fish to be correlated with avoidance of their consumption during pregnancy by Sikuani women, we used principal component analysis (PCA) to recognise the most important variables [27]. PCA was carried out using the PAST software [28].

\section{Results}

\section{Fish in the diet of the Sikuani women}

Participants recognised a total of 139 fish species consumed by Sikuani women. An important proportion of the fish species eaten by Sikuani women are avoided during menarche, menstruation, gestation, and postpartum, as shown in Table 1.

\section{Menarche}

In Sikuani culture, the first and most significant stage of female life cycle is the menarche, as this moment of a woman's life is a learning process in which the child acquires capabilities to play the roles of an adult. This knowledge is transmitted by the girl's mother and grandmother and involves the preparation of traditional foods such as cassava bread and yucuta (drink made from a type of mandioca), the management of home and family issues, among other skills.

The menarche renders the girl more susceptible to become sickened by the influence of ainawi, for this reason fish consumption is completely avoided by the girl until a ritual called the prayer of the fish is performed, usually 15 to 90 days after the onset of the first menstruation. Although the prayer of the fish is how this ceremony is commonly translated, it narrates the Sikuani creation myth not only of fish, but also of amphibians, reptiles, birds, and mammals that belong to ainawi spirits. In Sikuani language, the prayer of the fish is called Dujai matabajiwa that actually signifies the prayer of the ainawi. About the prayer, a leader of the community said "what the shaman communicate to the ainawi is that there is one more person who is going to feed on fish and ask for protection". The prayer of the fish consists of a chant that mentions 250 animals of aquatic habitat, according to the interviewees, in order to make an agreement with the ainawi to prevent the girl from being captured by them and to prevent disease. In the prayer of the fish, the girl's family invites relatives and the people of the region to celebrate with food, chants, and dances. Before the ritual begins, men of the girl's family fish as many species as possible. Women prepare and cook the fish to be prayed by the Sikuani shaman. During the prayer, all the fish of Sikuani regions are mentioned, from the smallest to the largest. After the prayer is done, the girl can eat fish, even when her next menstrual periods come. According to Sikuani tradition, when girls do not have the ritual or disrespect the dietary restrictions of menarche become more vulnerable to ailments caused by ainawi, a situation reminded by the myth of Bakatsolowa, a Sikuani story about a girl during her menarche who became a mermaid because of disobeying the restrictions related to fish consumption.

\section{Menstruation}

During menstruation, the consumption of piranha fish of the genus Serrasalmus is restricted, since it is associated with abundant menstrual bleeding due to the presence of sharp teeth and reddish colour on its pectoral and abdominal areas. In general, the interviewees affirmed that during menstruation, there are no other restrictions for the consumption of fish, since the prayer constitutes lifelong protection that allows women to eat all the fish species consumed by others in the community.

\section{Gestation}

It was found that among 139 fish species recognised as part of the Sikuani traditional diet, 66 were reported to be eaten during pregnancy while 73 are restricted. According to interviewees, fish with sharp teeth should not be eaten during pregnancy because they can "cut the umbilical cord with their teeth" and are associated with a higher occurrence of abortions. Piranha fish called in Sikuani sirribo and catzama (Serrasalmus rhombeus, Serrasalmus notatus, Pristobrycon striolatus) as well as jorojoro (Megalodoras irwini, Oxidoras niger), rakiraki (Platydoras costatus), and yayakato (Orinocodoras eigenmanni), which not only have sharp teeth but also have large fins, are considered to "detain the baby during labour". Small fish characterised by pointed tail or mouth are restricted during pregnancy since they are regarded as abortive, these include the dog toothed fish called kuejeto in Sikuani (Acestrorhynchus falcirostris) and the needlefish or tzuzubu in Sikuani (Farlowella vittata).

The intake of Tzama fish that has plaques on the skin is associated with an excessive sensation of heat at night and insomnia of the pregnant woman, it may also cause the baby to suffer from skin problems. The turuno or multo in Sikuani (Paulicea lutkeni) is a large omnivorous 
Table 1 Fish in the Sikuani diet during women's vital cycle

\begin{tabular}{|c|c|c|c|c|}
\hline Scientific taxa & Sikuani's name & $\begin{array}{l}\text { Is it eaten during } \\
\text { pregnancy? }\end{array}$ & $\begin{array}{l}\text { Is it eaten during menarche } \\
\text { and postpartum? }\end{array}$ & $\begin{array}{l}\text { Is it eaten during } \\
\text { menstruation? }\end{array}$ \\
\hline Curimatopsis macrolepis & Bajuto/sisieto & Yes & No & Yes \\
\hline Anchoviella guianensis & Wanaribajut & Yes & No & Yes \\
\hline Prochilodus nigricans & & Yes & No & Yes \\
\hline Prochilodus mariae & Kutzato & Yes & No & Yes \\
\hline Semaprochilodus kneri & & Yes & No & Yes \\
\hline Semaprochilodus laticeps & Jakato & Yes & No & Yes \\
\hline Astyanax abramis & - & Yes & No & Yes \\
\hline Astyanax bimaculatus & - & Yes & No & Yes \\
\hline Leporinus friderici & & Yes & No & Yes \\
\hline Leporinus fasciatus & Waracu & Yes & No & Yes \\
\hline Leporinus Moralesi & & Yes & No & Yes \\
\hline Schizodon fasciatus & Capirrito & Yes & No & Yes \\
\hline Laemolyta orinocensis & Doponito & Yes & No & Yes \\
\hline Anostomus anostomus & -Doponito & Yes & No & Yes \\
\hline Pseudanos gracilis & - & Yes & No & Yes \\
\hline Crenuchus spilurus & & Yes & No & Yes \\
\hline Hemiodopsis microlepis & Yonato & Yes & No & Yes \\
\hline Hemiodopsis semifasciatus & Yonato- & Yes & No & Yes \\
\hline Hemiodus gracilis & - & Yes & No & Yes \\
\hline Bryconops alburnoides & - & Yes & No & Yes \\
\hline Bryconops caudomaculatus & & Yes & No & Yes \\
\hline Chalceus macrolepidotus & Dopuento & Yes & No & Yes \\
\hline Apistogramma borellii & Kaleito & Yes & No & Yes \\
\hline Metynnis luna & Felefelwato & Yes & No & Yes \\
\hline Metynnis argenteus & Janeri & Yes & No & Yes \\
\hline Hemigrammus gracilis & Yaroto & Yes & No & Yes \\
\hline Hemigrammus micropterus & - & Yes & No & Yes \\
\hline Hemigrammus newboldi & & Yes & No & Yes \\
\hline Hemigrammus rhodostomus & Walabeto & Yes & No & Yes \\
\hline Hemigrammus unilineatus & - & Yes & No & Yes \\
\hline Mylossoma aureum & - & Yes & No & Yes \\
\hline Mylossoma duriventre & - & Yes & No & Yes \\
\hline Markiana geayi & - & Yes & No & Yes \\
\hline Microschemobrycon casiquiare & - & Yes & No & Yes \\
\hline Moenkhausia chrysargyrea & - & Yes & No & Yes \\
\hline Moenkhausia copei & - & Yes & No & Yes \\
\hline Moenkhausia cotinho & - & Yes & No & Yes \\
\hline Moenkhausia grandisquamis & - & Yes & No & Yes \\
\hline Moenkhausia megalops & - & Yes & No & Yes \\
\hline Moenkhausia intermedia & - & Yes & No & Yes \\
\hline Moenkhausia oligolepis & - & Yes & No & Yes \\
\hline Triportheus angulatus & - & Yes & No & Yes \\
\hline Triportheus orinocensis & & Yes & No & Yes \\
\hline
\end{tabular}


Table 1 Fish in the Sikuani diet during women's vital cycle (Continued)

\begin{tabular}{|c|c|c|c|c|}
\hline Scientific taxa & Sikuani's name & $\begin{array}{l}\text { Is it eaten during } \\
\text { pregnancy? }\end{array}$ & $\begin{array}{l}\text { Is it eaten during menarche } \\
\text { and postpartum? }\end{array}$ & $\begin{array}{l}\text { Is it eaten during } \\
\text { menstruation? }\end{array}$ \\
\hline Apistogramma ortmanni & Toseto & Yes & No & Yes \\
\hline Brycon falcatus & Buejato & Yes & No & Yes \\
\hline Brycon whitei & Wewerto & Yes & No & Yes \\
\hline Brycon siebenthalae & Kuejeto & Yes & No & Yes \\
\hline Brycon melanopterus & Yomatito & Yes & No & Yes \\
\hline Brycon pesu & & Yes & No & Yes \\
\hline Roeboides affinis & jawasirto & Yes & No & Yes \\
\hline Roeboides microlepis & Camalito & Yes & No & Yes \\
\hline Heterocharax macrolepis & C & Yes & No & Yes \\
\hline Tetragonopterus argenteus & Camalito & Yes & No & Yes \\
\hline Tetragonopterus chalceus & Camalito & Yes & No & Yes \\
\hline Markiana nigripinnis & Camalito & Yes & No & Yes \\
\hline Brachyplatystoma rousseauxii & & Yes & No & Yes \\
\hline Calophysus macropterus & Tsawijana & Yes & No & Yes \\
\hline Leiarius marmoratus & Tsawijana & Yes & No & Yes \\
\hline Pimelodus blochii & Tsaliuto & Yes & No & Yes \\
\hline Pimelodus clarias & Tsaliuto & Yes & No & Yes \\
\hline Pimelodus pictus & Tsaliuto & Yes & No & Yes \\
\hline Pseudoplatystoma tigrinum & Bunuju & Yes & No & Yes \\
\hline Zungaro zungaro & Paletono/sipari & Yes & No & Yes \\
\hline Aequidens chimantanus & Upeto, kaleito & Yes & No & Yes \\
\hline Aequidens diadema & & Yes & No & Yes \\
\hline Aequidens tetramerus & Upeto & Yes & No & Yes \\
\hline Astronotus ocellatus & Cabayuto & No & No & Yes \\
\hline Salminus hilarii & Wewerto & No & No & Yes \\
\hline Mikrogeophagus ramirezi & Kaleito & No & No & Yes \\
\hline Cichla temensis & Bofala & No & No & Yes \\
\hline Cichlasoma psittacum & Toseto & No & No & Yes \\
\hline Caquetaia kraussii & Kaleito & No & No & Yes \\
\hline Geophagus abalios & Upeto & No & No & Yes \\
\hline Colossoma macropomum & Katzama & No & No & Yes \\
\hline Piaractus brachypomus & & No & No & Yes \\
\hline Pristobrycon striolatus & Sirribo & No & No & Yes \\
\hline Synbranchus marmoratus & Watsupi & No & No & No \\
\hline Hypostomus punctatus & Tzama & No & No & Yes \\
\hline Sorubim lima & Karresobo & No & No & Yes \\
\hline Batrochoglanis villosus & Multo & No & No & Yes \\
\hline Bryconamericus cismontanus & Yepe & No & No & Yes \\
\hline Serrasalmus rhombeus & Catzama/tatama & No & No & No \\
\hline Serrasalmus notatus & Sirribo & No & No & No \\
\hline Acestrorhynchus falcirostris & Kuejeto & No & No & Yes \\
\hline Acestrorhynchus falcatus & Awirri & No & No & Yes \\
\hline Acestrorhynchus microlepis & Agujombo & No & No & Yes \\
\hline
\end{tabular}


Table 1 Fish in the Sikuani diet during women's vital cycle (Continued)

\begin{tabular}{|c|c|c|c|c|}
\hline Scientific taxa & Sikuani's name & $\begin{array}{l}\text { Is it eaten during } \\
\text { pregnancy? }\end{array}$ & $\begin{array}{l}\text { Is it eaten during menarche } \\
\text { and postpartum? }\end{array}$ & $\begin{array}{l}\text { Is it eaten during } \\
\text { menstruation? }\end{array}$ \\
\hline Acestrorhynchus nasutus & Patirribo & No & No & Yes \\
\hline Rhaphiodon gibbus & Patirribo & No & No & Yes \\
\hline Hydrolycus scomberoides & Wemai & No & No & Yes \\
\hline Hydrolycus tatauaia & & No & No & Yes \\
\hline Hoplerythrinus unitaeniatus & Enowü & No & No & Yes \\
\hline Hoplias malabaricus & Tsumera & No & No & Yes \\
\hline Boulengerella cuvieri & - & No & No & Yes \\
\hline Boulengerella lateristriga & & No & No & Yes \\
\hline Boulengerella lucius & Tsutsubo & No & No & Yes \\
\hline Boulengerella maculata & Tutsipabo & No & No & Yes \\
\hline Ochmacanthus alternus & Wena & No & No & Yes \\
\hline Acestridium colombiensis & - & No & No & Yes \\
\hline Acestridium martini & & No & No & Yes \\
\hline Rineloricaria magdalenae & Bosikito & No & No & Yes \\
\hline Rineloricaria formosa & Bosikito & No & No & Yes \\
\hline Farlowella vittata & Tzutzubo & No & No & Yes \\
\hline Loricaria cataphracta & Bosikito & No & No & Yes \\
\hline Panaque cochliodon & Werria & No & No & Yes \\
\hline Hypostomus ammophilus & Tzama & No & No & Yes \\
\hline Hypostomus plecostomus & Tzama & No & No & Yes \\
\hline Hypostomus watwata & Tzama & No & No & Yes \\
\hline Pterygoplichthys gibbiceps & Tzama & No & No & Yes \\
\hline Guianacara geayi & Tzama & No & No & Yes \\
\hline Pterygoplichthys punctatus & Tzama & No & No & Yes \\
\hline Paulicea lutkeni & Multo & No & No & Yes \\
\hline Batrochoglanis raninus & Torito & No & No & Yes \\
\hline Rhamdia wagneri & Rakiraki & No & No & Yes \\
\hline Agamyxis albomaculatus & Yayakato & No & No & Yes \\
\hline Platydoras costatus & Rakiraki & No & No & Yes \\
\hline Hoplosternum littorale & Kokoto & No & No & Yes \\
\hline Hydrolycus armatus & Tátama & No & No & Yes \\
\hline Megalodoras irwini & Tátama & No & No & Yes \\
\hline Orinocodoras eigenmanni & Yayakato & No & No & Yes \\
\hline Ageneiosus inermis & & No & No & Yes \\
\hline Crenicichla geayi & Bopi & No & No & Yes \\
\hline Crenicichla Johanna & - & No & No & Yes \\
\hline Crenicichla lugubris & & No & No & Yes \\
\hline Crenicichla saxatilis & Bajiwi & No & No & Yes \\
\hline Mesonauta egregius & Toseto & No & No & Yes \\
\hline Curimata spilura & Kerpainto & No & No & Yes \\
\hline Curimatopsis evelynae & Upato & No & No & Yes \\
\hline Cichlasoma severum & Mamarto & No & No & Yes \\
\hline Brachyplatystoma filamentosum & Pelsi & No & No & Yes \\
\hline
\end{tabular}


Table 1 Fish in the Sikuani diet during women's vital cycle (Continued)

\begin{tabular}{|c|c|c|c|c|}
\hline Scientific taxa & Sikuani's name & $\begin{array}{l}\text { Is it eaten during } \\
\text { pregnancy? }\end{array}$ & $\begin{array}{l}\text { Is it eaten during menarche } \\
\text { and postpartum? }\end{array}$ & $\begin{array}{l}\text { Is it eaten during } \\
\text { menstruation? }\end{array}$ \\
\hline Brachyplatystoma juruense & Kajuyali topa & No & No & Yes \\
\hline Brachyplatystoma vaillantii & - & No & No & Yes \\
\hline Pseudoplatystoma fasciatum & Pelsi & No & No & Yes \\
\hline Phractocephalus hemiliopterus & Dome & No & No & Yes \\
\hline Platynematicthys notatus & - & No & No & Yes \\
\hline Sorubimichthys planiceps & & No & No & Yes \\
\hline Electrophorus electricus & Kubebe & No & No & No \\
\hline Cichla nigrolineatus & Bofala & No & No & Yes \\
\hline Oxydoras niger & Jorojoro & No & No & Yes \\
\hline Potamotrygon hystrix & Tulupo pone & No & No & Yes \\
\hline
\end{tabular}

fish that can "take away the soul and cause death" of babies when eaten by pregnant women. The consumption of the electric eel or kubebe (Electrophorus electricus) is restricted during pregnancy because of its cylindrical and snake-like shape; however, its burned bone is used to facilitate labour because the fish skin is very smooth, and this feature is associated with a rapid delivery.

According to the interviewees, the consumption of certain fish can have effects on the physical characteristics and personality of newborns. For example, bajiwi are small fish with a spot on its tail peduncle that resembles an eye, and they should not be eaten during pregnancy because their consumption is associated with babies born with red eyes who become shy in the future. Similarly, if the pregnant woman eats a medium-sized fish with pointed teeth called dormilon, guabina, or tsumera in Sikuani (Hoplerythrinus unitaeniatus), it is associated with infants that eat rubbish when start to crawl.

\section{Principal component analysis}

According to PCA results, the principal component 1 (PC1) explained $74.96 \%$ of the data variation. The most important variables of $\mathrm{PC} 1$ were the type of feeding and size of the fish (eigenvalues 0.9 and 0.35 respectively) and therefore are the most determining characteristics for dietary avoidance or allowance of fish during pregnancy. In PC2, the most important variables were the size of the fish and the presence of barbels (eigenvalues 0.88 and 0.22 respectively). In Fig. 2, PC1 is represented on the $X$ axis and in $\mathrm{PC} 2$ on the $Y$ axis. The fish considered edible during pregnancy are represented with blue triangles, while the restricted ones with red squares. The fish avoided during pregnancy correspond mainly to big carnivorous or omnivorous fish that can have barbells on their jaw, these are included in groups $C$ and $D$. However, group $\mathrm{C}$ also includes two blue triangles that represent medium-sized but carnivorous or omnivorous fish with barbells that are eaten during gestation. The majority of small fish are eaten during pregnancy, with the exception of those that have a spot on their caudal peduncle or a pointed mouth or tail (groups A and B).

\section{Postpartum}

The period between birth and the next 40 days postpartum is very important for Sikuani people since the baby's health and vitality depend on the care received during this period of time. At this stage, the parents use to limit their duties; the father must neither hunt nor work and the woman must designate her housework to other women in the community such as her mother or sisters, since otherwise the navel of the newborn can bleed. During the first days of postpartum, the woman and her husband avoid fish consumption until the prayer of the fish takes place. In this occasion, the ritual is not performed as a collective celebration, it is an intimate setting. Once the child begins, the complementary diet, the prayer of the fish is made to introduce the new member of the community to the ainawi, in order to prevent the disease.

\section{Discussion}

Fish size, trophic level, and toxicity

According to Sikuani traditional knowledge, there are relations between fish consumption and woman health along the reproductive cycle. Sikuani women avoid eating certain fish during menarche, menstruation, pregnancy, and postpartum as its consumption is related with traditional ailments. According to the results of this study, the fish size and its feeding habits are the most important characteristics associated with the avoidance of its consumption by pregnant Sikuani women. Regarding the feeding habits, carnivorous fish are not eaten during pregnancy, compared to herbivores and insectivorous species, which are eaten unless they have other specific banning characteristics. Pregnant Sikuani women also abstain 


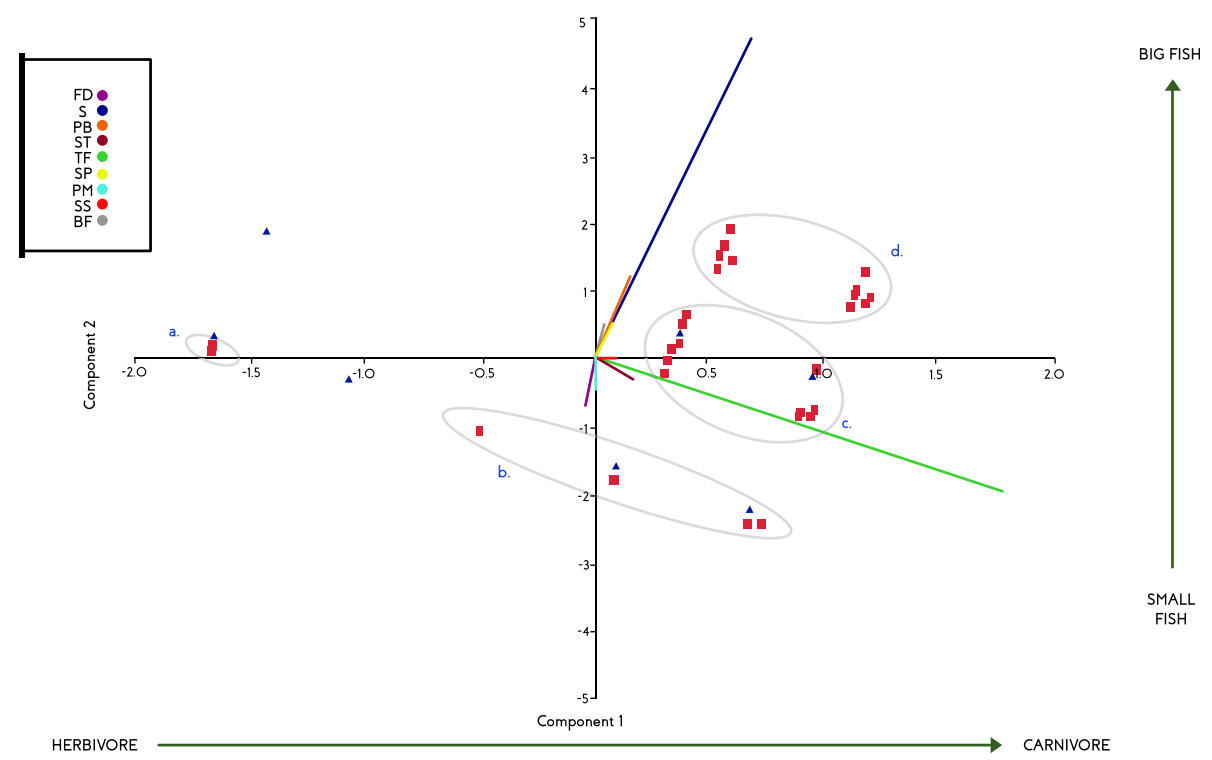

Fig. 2 PCA of morphological features of fish and selection or restriction on diet during pregnancy. TF, type of food; S, size; ST, sharp teeth; BF, big fins; PB, presence of barbels; PM, peaked mouth or acuminate caudal peduncle; FD, fish that disguise or presence of spot at the caudal peduncle; PP, skin in plates; SS, snake shape. Blue triangles represent edible fish and red squares restricted fish during pregnancy. Groups A, B, C, and D delimited in ovals represent most of the species restricted during pregnancy. Green axis represents PC1 and blue axis PC2

from eating sharped-teeth fish as its consumption is associated with abortions; this morphological feature is commonly found in carnivorous fish. Previous studies have reported that inhabitants of Brazilian Amazon and Atlantic coast during the menstruation and the puerperium, as well as when recovering from diseases as injuries or wounds, avoid the consumption of carnivorous fish, as well as fish of aggressive behavior, hard flesh, high-fat content, or without scales, preferring herbivorous, insectivorous, and detritivorous species [29].

Large and carnivorous fish are at higher trophic levels than smaller and non-carnivorous ones. It has been evidenced that animals at upper levels of the food chain, such as carnivorous fish, tend to bioaccumulate toxins like heavy metals or plaguicides from eating plants and animals at lower trophic levels. Pesticides like DDT (dichloride diphenyl trichloroethane) have been detected in fish flesh in levels 10 times higher when it is ingested through the diet rather than through water [30]. Carnivorous fish also bioaccumulate greater amounts of heavy metals than omnivorous, detritivores, insectivorous, and herbivorous species. Previous studies about mercury, methylmercury, lead, cadmium, and metalloid arsenic concentrations on fish from Colombian rivers have evidenced higher levels of these heavy metals in the flesh of carnivorous fish when compared to non-carnivorous ones [31-33]. The amount of heavy metals on Colombian fish exceed the maximum levels recommended by the World Health Organisation and the consumption of fish from mining regions have been directly associated with high concentrations of heavy metals detected in humans [34]. The regulation of carnivorous fish consumption by Sikuani women during important life stages may have beneficial effects on health, decreasing the intake of toxins accumulated on these species. The avoidance of carnivorous fish by inhabitants of the Brazilian Amazonas and Atlantic Coast has been considered a strategy to adapt to changing environmental conditions and to preserve health [29].

\section{Signatures of ainawi}

During menarche, menstruation, pregnancy, and postpartum Sikuani women regulate the consumption of fish, because it is considered to cause illness if ainawi, as protector spirits of water and animals are not asked for permission previously. Other American indigenous groups like Mapuche, Quechua, and Aymara people also believe in the existence of spiritual beings who are considered protectors or owners of all-natural resources, entities that must be requested for permission when humans plan to visit their habitats or eat animals [35-38].

Most of the regulations of fish consumption during pregnancy among Sikuani women may be interpreted as associations of similarity conceived between the morphology, diet and other aspects of fish, and the effects they generate on women and foetus health. According to informants, these fish features are traditionally comprehended as an expression of the force of its ainawi and its potency to cause disease to humans. This reasoning may be analysed using the theories of sympathetic magic 
and the doctrine of signatures. Sympathetic magic underlies diverse traditions, rituals, and conceptions; it operates through the law of contagion in which contacted objects transfer some of their properties, eliciting consequences that may be temporary or permanent. The doctrine of signatures holds that similar objects may exert an action or effect related to their shapes or functions, as might be the case of certain foods that are avoided because they resemble undesirable characteristics or conditions [39]. The interviewees consider the ainawi of fish may persist after eating them and are able to provoke health problems to the pregnant woman and the foetus, evidencing concepts of contagion [39]. It is also stated by the informants that some characteristics of fish give information about the health conditions or ailments they can induce, features conceived as signatures of ainawi on fish. In a similar way, other indigenous communities believe animals can transfer their characteristics to people who eat them. As referred by Sikuani people from Wacoyo Reservation, the shakerfish (Electrophorus electricus) has been also used to facilitate deliveries in Spanish ethnomedicine [40]. Some communities from Ghana circumvent the intake of snakes during pregnancy, as it is associated through similarities with dry scaly skin in the newborn [41]. At the Peruvian Amazon, the speakers of Iquitos language consider the meat of fish and mammals with sharp teeth may be harmful to people recovering from disease, as it resembles the magical darts used by witches to attack their victims [42].

\section{Prayers to ainawi}

Sikuani people consider the prayer of the fish a formal introduction of community members to the spirits of nature during important life stages; in order to prevent ainawi-associated ailments. The fish features associated with disease are reflected on the prayer of the fish, as the first fish to be referred at the beginning of the myth are the smallest ones and are almost always considered edible for Sikuani women, while large and carnivorous fish are mentioned at the end of the prayer and are more commonly forbidden during specific stages of life. Since this point of view, the order of appearance of fish on the myth can be related with the symbolic introduction of animals into Sikuani diet after menarche or birth, beginning with the less harmful ones and ending with animals whose consumption is closely related to ainawi ailments.

The prayer of the fish ceremony is related to the Sikuani story of Bakatsolowa, a girl who became a mermaid after eating fish without the ritual of menarche. This myth refers to girls' vulnerability of being captured and abducted into the underworld or fish world by the ainawi. This narration acts as a reminder in Sikuani culture about the restrictions on fish consumption during specific moments of the life cycle or when recovering from disease, and also about the importance of the prayer of the fish as a traditional preventive measure.

Likewise, other communities from different regions of the world have similar food regulations and rituals associated with the first menstruation, as is the case of a traditional community in Sri Lanka in which during menarche and while the menstrual bleeding lasts, the girl receives a diet without fish, oils, and spices to protect her from future diseases. Once the restriction ends, there is a celebration with relatives, friends, and neighbors where several dishes are served, including those previously avoided by the girl [43].

\section{Diet regulations and socio-ecological health and resilience}

Sikuani people consider the avoidance of certain foods at specific stages of life and the associated rituals like the prayer of the fish, are traditional approaches to preserve human health, to maintain the balance of ecosystems, to prevent natural resources extinction, and to reinforce social cohesion in their communities. The majority of regulations upon fish consumption during menarche, menstruation, pregnancy, and postpartum among Sikuani women from Wacoyo Reservation are directed toward prevention of woman disease, problems during childbirth and diseases, malformations in the newborn or other ainawi-associated ailments. Health reasons for food avoidance are also reported in other communities, the Kalenjin women from Kenya evade the consumption of certain foods to prevent neonatal death, skin lesions, abortions, and premature birth [44]. Women from Myanmar avoid during the postpartum to eat certain kinds of fish considered not suitable for mothers' and babies' health [45].

Some authors state that restrictions for the utilisation of natural resources among traditional societies can be understood as ecological adaptations to maintain the resilience of ecosystems and social groups [46]. The relationship that Sikuani communities have established with nearby rivers fish, transcends the physical and involves an interaction between nature and culture, between supernatural and human [47]. The Sikuani of the Wacoyo Reservation have managed to conserve their traditions despite the significant reduction of their territory due to appropriation of their ancestral lands by settlers [7]. Nowadays, these dietary customs are changing and might disappear, as most of health and nutrition conceptions or practices of Sikuani people are frequently ignored or rejected at hospitals or other institutions; an issue threatens the use of indigenous foods and provokes a progressive decline of traditional food systems [4]. The inclusion of traditional Sikuani knowledge in the formulation and implementation of policies involving their 
communities may constitute an important contribution to develop intercultural strategies to solve health issues and for the sustainable management of natural resources.

\section{Conclusions}

The traditional diet of Sikuani women includes numerous fish species and an important proportion of them are avoided during menarche, menstruation, gestation, and postpartum. It was found that during menarche and postpartum, fish consumption is avoided by Sikuani women only before the ritual known as the prayer of the fish is performed. The menstruation does not imply significant regulations for fish intake, while during pregnancy there are multiple and specific avoidances for consumption of fish. According to our results, there are some features of fish associated with their regulation on the diet of pregnant Sikuani women, who evade to eat mainly carnivorous, large, or sharp teeth fish, as well as fish with plaques, pointed mouth, or tail or with a spot on their caudal peduncle. The consumption of these kinds of fish is avoided during pregnancy because it is related to the appearance of disease caused by ainawi, protector spirits of aquatic animals. The aim of the traditional Sikuani ceremony called prayer of the fish is to intercede with the ainawi to ask for protection for the members of the community that feed on fish and other aquatic animals. The regulations among Sikuani people for the consumption of carnivorous fish may be related to their higher trophic level and with the fact these species accumulate a greater amount of toxins like plaguicides and heavy metals. The main reasons underlying the avoidance of fish consumption by Sikuani women are the prevention of human disease as well as the strengthening of communities and ecosystems resilience. Further studies to evaluate the impacts on nutrition of traditional foods and the effects of regulations for their consumption among Sikuani people are recommended.

\section{Abbreviations}

PCA: Principal component analysis

\section{Acknowledgements}

The authors are fully grateful with the local inhabitants of the Wacoyo indigenous reservation for sharing their knowledge on their practices during the different moments in the vital cycle of the Sikuani women, for their good reception and collaboration during the development of the project. We also appreciate the support of Alexander Díaz, leader of the community and knowledge sharing manager.

We wish to thank Dr. Juan Jose Viecco who made contact with the community and taught us the way of approach to the people. Also, we are grateful with the medical students of the National University of Colombia: Karen Daniela Micán Ruiz, Sergio Parada, Juliana Hernández, and David Gaona, for their company at the fieldwork and help in the collection and classification of information. Also, our loving gratitude to the National University of Colombia.

\section{Authors' contributions}

CV idealized the study, guided the method, analyzed the information, and worked in the discussion. LC designed and coordinated the project, analyzed the information, and wrote the manuscript. DM gathered, classified, and analyzed the information. All authors read, reviewed, and approved the final manuscript.

\section{Funding}

This research was funded by the National University of Colombia.

\section{Availability of data and materials}

Additional data on the interviews is available from the first author upon request.

\section{Ethics approval and consent to participate}

This study was conducted according to the ethics quidelines of ISE Code of Ethics (http://ethnobiology.net/code-of-ethics/). All fieldwork was approved by the Research Ethics Committee of the school of medicine of the National University of Colombia. Permissions were obtained from all participants of this study. In accordance with article 11 of Resolution 008430 of 1993 of the Ministry of Health of Colombia, this is a risk-free research.

\section{Consent for publication}

Leaders of Wacoyo Reservation agreed with the project and publication of the results.

\section{Competing interests}

The authors declare that they have no competing interests.

Received: 31 October 2018 Accepted: 27 August 2019

Published online: 10 October 2019

\section{References}

1. Unigarro C. Sistemas alimentarios y patrimonio alimentario. Transculturaciones en el caso ecuatoriano. Antropología Cuadernos de investigación. 2015;15:21-34 http://www.cuadernosdeantropologia-puce. edu.ec/index.php/antropologia/article/view/38.

2. Mintz SW, Du Bois CM. The anthropology of food and eating. Ann Rev Anthropol. 2002;31:99-119.

3. Madden $\mathrm{H}$, Chamberlain K. Nutritional health, subjectivity and resistance: women's accounts of dietary practices. Health. 2010;14:292-309.

4. Kuhnlein HV, Receveur O. Dietary change and traditional food systems of indigenous peoples. Ann Rev Nutr. 1996;16:417-42.

5. Meyer-Rochow VB. Food taboos: their origins and purposes. J Ethnobiol Ethnomed. 2009;5:18.

6. Placek CD, Madhivanan P, Hagen EH. Innate food aversions and culturally transmitted food taboos in pregnant women in rural southwest India: Separate systems to protect the fetus? Evol Hum Behav. 2017;38:714-28.

7. Navarrete CD, Fessler D. Meat is good to taboo: dietary proscriptions as a product of the interaction of psychological mechanisms and social processes. J Cogn Cult. 2003;3:1-40.

8. Plata AM. Importancia de la fauna silvestre en la etnia Sikuani, comunidad de Cumarianae, selva de Matavén, Vichada, Colombia. In: Thesis of specialization. Colombia: Universidad Sergio Arboleda, Bogotá; 2005. https:// www.usergioarboleda.edu.co/wp-content/uploads/2012/06/fauna-sivestrevichada-colombia.pdf.

9. Calle L, Ph.D Thesis. La incansable búsqueda de El Dorado. Procesos hegemónicos y dispositivos de dominación en un pueblo Sikuani de la Orinoquía colombiana. Universidad Complutense de Madrid. 2015. https:// eprints.ucm.es/37892/.

10. Denevan WM. The pristine myth: the landscape of the Americas in 1492. In: Annals of the Association of American Geographers; 1992. https://doi.org/1 0.1111/j.1467-8306.1992.tb01965.x.

11. Etter A, McAlpine C, Possingham $\mathrm{H}$. Historical patterns and drivers of landscape change in Colombia since 1500: a regionalized spatial approach. Ann Assoc Am Geogr. 2008;98:2-23.

12. Castro LM. Guahibo-Sikuani. In: Romero ME, Castro LM, Muriel A, editors. Geografía Humana de Colombia Región Orinoquía. Bogota: Instituto Colombiano de Cultura Hispánica; 2000. p. 168-224.

13. Torres MA, Rubio MA, Trujillo JM. Approximation of the socio-cultural importance of the Moriche palm tree (Mauritia fleuxuosa LF) in the Wacoyo 
indigenous community (Sikuani) in the municipality of Puerto Gaitán, Colombia. Orinoquia. 2015;19:231-6

14. Calle L. Entre La Violencia, la colonización y la adjudicación de reservas. Relatos sikuanis sobre el abandono, el despojo y la recuperación del territorio. Revista Colombiana de Antropología. 2017;53:91-122 www.scielo. org.co/scielo.php?script=sci_arttext\&pid=S0486-65252017000100091\&lng= en\&tlng=es.

15. Sánchez LF. Caracterización de los grupos humanos rurales de la cuenca hidrográfica del Orinoco en Colombia. Bogotá: Instituto de Investigación de Recursos Biológicos Alexander von Humboldt; 2003. http://repository. humboldt.org.co/handle/20.500.11761/9872.

16. Ariza E, Polanco R, Yepes A, Suárez A. Matavén: territorio, cultura y paisajes. Bogotá: Instituto Colombiano de Antropología e Historia; 2006.

17. Reichel G. La cultura material de los indios Guahibo. In: Revista del Instituto Etnológico Nacional. ICANH. 1943. http://www.icanh.gov.co/index. php?idcategoria=8137. Accessed 1 April 2019.

18. Ortiz F. El rezo del pescado: Ritual de pubertad femenina entre los Sikuani y Cuiba: Maguaré; 1989. p. 27-67. https://revistas.unal.edu.co/index.php/ maguare/article/view/14222/15010.

19. Bautista K, Jiménez R, Roelens T. El canto de los peces: Los seres del agua en la mitología y la vida cotidiana de los indígenas sikuani del Vichada. Bogota: Colciencias; 1994.

20. Johannes W. Notes on Guahibo Kinship and Social Organization. Southwestern J Anthropol. 1957;13:88-98 https://doi.org/10.1086/ soutjanth.13.1.3629159.

21. Bodoque Y. Tiempo biológico y tiempo social. Aproximación al análisis del ciclo de vida de las mujeres. In: Revista Gazeta de Antropología; 2001. p. 17. http://hdl.handle.net/10481/7472.

22. Saunders B, Sim J, Kingstone T, Baker S, Waterfield J, Bartlamb B, et al. Saturation in qualitative research: exploring its conceptualization and operationalization. Qual Quant. 2018:52:1893 https://doi.org/10.1007/s11135017-0574-8.

23. Prosser J. What Constitutes an Image-based Qualitative Methodology? Visual Sociology. 1996;11:25-34 https://doi.org/10.1080/14725869608583763.

24. Rubio H, Ulloa A, Rubio M. Tras las huellas de los animales: 23 especies del Chocó biogeográfico. Bogotá: Fundación Natura; 1998.

25. Usma J, et al. Peces de la cuenca del río Meta. In: Trujillo F, Antelo R, Usma S, editors. Biodiversidad de la cuenca baja y media del río Meta. Bogotá: Fundación Omacha, Fundación Palmarito, WWF; 2016. p. 105-22.

26. Wilson V. Research methods: triangulation. Evid Based Libr Infor Pract. 2014;9:74-5.

27. Höft M, Barik SK, Lykke AM. Quantitative ethnobotany: applications of multivariate and statistical analyses in ethnobotany. In: People and Plants working paper 6. 1999. https://www.researchgate.net/profile/Anne_Mette_ Lykke/publication/235654831_Quantitative_Ethnobotany_Applications_of_ Multivariate_and_Statistical_Analyses_in_Ethnobotany/links/02bfe512523 fdd73a4000000/Quantitative-Ethnobotany-Applications-of-Multivariate-andStatistical-Analyses-in-Ethnobotany.pdf. Accesed 20 Jun 2018

28. Hammer $\varnothing$, Harper DAT, Ryan PD. PAST: Paleontological statistics software package for education and data analysis. Palaeontol Electron. 2001. https://www.researchgate.net/profile/David_Harper8/publication/25 9640226_PAST_Paleontological_Statistics_Software_Package_for_ Education_and_Data_Analysis/links/554cbe7c0cf29752ee7fa18f/PASTPaleontological-Statistics-Software-Package-for-Education-and-DataAnalysis.pdf. Accesed on 20 Jun 2018.

29. Begossi A, Hanazaki N, Ramos RM. Food chain and the reasons for fish food taboos among amazonian and atlantic forest fishers (Brazil). Ecol Appl. 2004; 14:1334-43.

30. Macek KJ, Korn S. Significance of the food chain in DDT accumulation by fish. J Fish Board Canada. 1970;27:1496-8.

31. Marrugo-Negrete J, Verbel JO, Ceballos E, Benitez LN. Total mercury and methylmercury concentrations in fish from the Mojana region of Colombia. Environ Geochem Health. 2008;30:21-30.

32. Alvarez S, Jessick AM, Palacio JA, Kolok AS. Methylmercury concentrations in six fish species from two Colombian rivers. Bull Environ Contam Toxicol. 2012:88(1):65-8.

33. López-Barrera EA, Barragán-Gonzalez RG. Metals and metalloid in eight fish species consumed by citizens of Bogota DC, Colombia, and potential risk to humans. J Toxicol Environ Health Part A. 2016;79(5):232-43.

34. Olivero J, Johnson B, Arguello E. Human exposure to mercury in San Jorge river basin, Colombia (South America). Sci total Environ. 2002;289(1-3):41-7.
35. Politis G, Saunders N. Archaeological correlates of ideological activity: food taboos and spirit-animals in an Amazonian hunter-gatherer society. In: Miracle P, Milner N, editors. Consuming passions and patterns of consumption. Cambrige: McDonald Institute for Archaeological Research; 2002. p. 113-30

36. Aigo J, Ladio A. Traditional Mapuche ecological knowledge in Patagonia, Argentina: fishes and other living beings inhabiting continental waters, as a reflection of processes of change. J Ethnobiol Ethnomedicine. 2016;12:56.

37. Thomas E, Vandebroek I, Van Damme P, Semo L, Noza Z. Susto etiology and treatment according to Bolivian Trinitario people: a "masters of the animal species" phenomenon. Med Anthropol Q. 2009:23:298-319.

38. Grebe ME. El culto a los animales sagrados emblemáticos en la cultura aymara de Chile. Revista Chilena de Antropología. 1989. https://revistas. uchile.cl/index.php/RCA/article/download/17599/18363/.

39. Rozin P, Nemeroff $C$, Wane M, Sherrod A. Operation of the sympathetic magical law of contagion in interpersonal attitudes among Americans. Bull Psychon Soc. 1989; https://doi.org/10.3758/BF03334630.

40. Vallejo JR, González JA. Fish-based remedies in Spanish ethnomedicine: a review from a historical perspective. J Ethnobiol Ethnomed. 2014;10:37.

41. Arzoaquoi SK, Essuman EE, Gbagbo FY, Tenkorang EY, Soyiri I, Laar AK. Motivations for food prohibitions during pregnancy and their enforcement mechanisms in a rural Ghanaian district. J Ethnobiol Ethnomed. 2015;11:59. https://doi.org/10.1186/s13002-015-0044-0.

42. Jernigan KA. Dietary restrictions in healing among speakers of Iquito, an endangered language of the Peruvian Amazon. Journal of ethnobiology and ethnomedicine. 2012;7:20

43. Winslow D. Rituals of first menstruation in Sri Lanka. Man, New Series. 1980; 15:603-25.

44. Riang'a RM, Broerse J, Nangulu AK. Food beliefs and practices among the Kalenjin pregnant women in rural Uasin Gishu County, Kenya. Journal of Ethnobiology and Ethnomedicine. 2017;13:29.

45. Diamond-Smith N, Thet MM, Khaing EE, Sudhinaraset M. Delivery and postpartum practices among new mothers in Laputta, Myanmar: intersecting traditional and modern practices and beliefs. Culture, health \& sexuality. 2016;18(9):1054-66 https://doi.org/10.1080/13691058.2 016.1144792 .

46. Berkes F, Colding J, Folke C. Rediscovery of traditional ecological knowledge as adaptive management. Ecol Appl. 2000. https://doi.org/10.2307/2641280.

47. Turbay S. Aproximaciones a los estudios antropológicos sobre la relación entre el ser humano y los animales In: Ulloa A, editor. Rostros culturales de la fauna. Colombia: Instituto Colombiano de Antropología e Historia y Fundación Natura; 2002. p. 87-112.

\section{Publisher's Note}

Springer Nature remains neutral with regard to jurisdictional claims in published maps and institutional affiliations.

Ready to submit your research? Choose BMC and benefit from:

- fast, convenient online submission

- thorough peer review by experienced researchers in your field

- rapid publication on acceptance

- support for research data, including large and complex data types

- gold Open Access which fosters wider collaboration and increased citations

- maximum visibility for your research: over $100 \mathrm{M}$ website views per year

At $\mathrm{BMC}$, research is always in progress.

Learn more biomedcentral.com/submissions 